\title{
Analisis Ketepatan Dalam Mengetahui Diagnosa Keperawatan Dalam Perenanaan Asuhan Keperawatan
}

\author{
tasyahalawa1705@gmail.com
}

\section{Latar Belakang}

Dokumentasi keperawatan adalah catatan asuhan keperawatan yang direncanakan dan dikirimkan ke pasien individu oleh perawat yang berkualifikasi atau pengasuh lain di bawah arahan perawat yang berkualifikasi. Dokumentasi adalah catatan otentik dalam penerapan manajemen asuhan keperawatan profesional. Perawat yang profesional diharapkan mampu menghadapi tuntutan tanggung jawab dan akuntabilitas atas segala tindakan yang dilakukan. Kesadaran masyarakat akan hukum semakin meningkat sehingga dibutuhkan dokumentasi yang lengkap dan jelas.

Keperawatan adalah suatu bentuk pelayanan profesional yang merupakan bagian integral dari pelayanan kesehatan berdasarkan ilmu dan kiat keperawatan berbentuk pelayanan biologis, psikologis, sosiologis dan spiritual yang komprehensif/holistik yang ditujukkan kepada individu, keluarga dan masyarakat baik dalam keadaan sehat atau sakit yang mencakup seluruh proses kehidupan manusia yang mengacu pada standar profesional keperawatan dan menggunakan etika keperawatan sebagai tuntutan utama Dalam tahap diagnosa, perawat berperan secara independen, artinya perawat dapat merumuskan sendiri diagnosanya, bertanggung jawab terhadap diagnosa yang dirumuskan, membedakan peran perawat dengan peran dokter, serta menunjukkan bahwa asuhan keperawatan tersebut bermutu, mempunyai kualitas, dan atas dasar pendidikan perawat.

Diagnosa merupakan salah satu tahap dalam proses keperawatan, yang dilakukan setelah pengkajian. Diagnosa keperawatan adalah proses menganalisis data yang didapatkan melalui proses pengkajian untuk menegakkan diagnosa. Sebelum merumuskan diagnosa, perawa memiliki tanggung jawab untuk mengenal atau mengidentifikasi masalah kesehatan klien Untuk mengidentifikasi kebutuhan 
klien, perawat harus lebih dulu menentukan apakah masalah kesehatan pasien tersebut aktual atau potensial. Perawat bertugas memberikan asuhan keperawatan yang berkualitas.

\section{Metode}

Metode yang digunakan oleh penulis dalam kajian ini adalah literature review, yaitu dengan cara menganalisis, mengeksplorasi serta mengkaji bebas jurnal dan buku teks yang membahas tentang pentingnya ketepatan dalam menegakkan diagnosa. Referensi berupa jurnal dan buku teks yang digunakan adalah sebanyak 10 Jurnal. Tulisan ini didasarkan dengan menganalisis berbagai karya penelitian yang berfokus pada "Analisis Ketepatan Dalam Mengetahui Diagnosa Keperawatan Dalam Perenanaan Asuhan Keperawatan" Dari hasil pencarian kemudian diolah dan dianalisis sehingga menghasilkan sebuah pembahasan dan kesimpulan dari topik yang ditetapkan Metode dari penulisan ini dilakukan untuk menjelaskan bagaimana menentukan diagnosa keperawatan dalam asuhan keperawatan.

\section{Hasil}

Berdasarkan hasil pencarian literatur di dapatkan peran perawat dalam melakukan pengkajian diagnosa keperawatan pasien di rumah sakit, dimana di dalam literature review terebut Proses keperawatan merupakan suatu sistem yang disusun secara sistematis dalam pemberian asuhan keperawatan. Dalam proses keperawatan, diagnosa merupakan tahap kedua setelah pengkajian. Perawat bertanggung jawab untuk merumuskan diagnosa dengan menggunakan data-data yang terkumpul selama proses pengkajian. Diagnosa merupakan dasar untuk menentukan intervensi keperawatan yang tepat dan berkulitas. Oleh karena itu, diagnosa keperawatan yang dirumuskan atau ditegakkan oleh perawat harus tepat.

Salah satu kegiatan yang penting dalam proses keperawatan adalah pengkajian keperawatan. Pengalaman menunjukkan bahwa sering sekali perawat kesulitan dalam menentukan diagnosis keperawatan spesifik yang dialami oleh pasien.Hal ini mungkin karena pengkajian keperawatan yang tidak terstruktur dengan baik. Sejauh ini belum ada standar asuhan keperawatan Perawat sebagai tenaga kesehatan yang bertugas untuk memenuhi kebutuhan dasar klien secara 
holistic memiliki tanggung jawab untuk membantu pemenuhan kebutuhan oksigen klien yang tidak adekuat.Dalam tindakannya, seorang perawat sebelum memberikan asuhan keperawatanharus melakukan metode keperawatan berupa pengkajian, diagnosis keperawatan, intervensi, dan evaluasi.

Layanan asuhan keperawatan yang baik harus terstruktur dan berkelanjutan, ini akan memudahkan perawat dalam menangani masalah pasien. Pemberian asuhan keperawatan terkadang tidak akurat karena kelalaian perawat sehingga dibutuhkan sebuah pedoman yang dapat memuat data-data asuhan keperawatan yang mudah diakses dan digunakan. Aplikasi ini berguna untuk membantu perawat melakukan tugas secara efektif dan efisien karena aplikasi ini dilengkapi dengan data asuhan keperawatan berbasis NANDA, dan, NIC-NOC. Profesi perawat menggunakan proses keperawatan (nursing process) sebagai kerangka pikir dan kerangka kerja dalam merawat pasien. Keperawatan sebagai proses, diperkenalkan sejak tahun 1955 oleh Hall dan pada tahun 2004 proses keperawatan (nursing process) ditetapkan

sebagai series of steps oleh ANA (American Nursing Association) yang terdiri dari assesment (pengkajian), diagnosis (penetapan diagnosis), planning outcomes (perencanaan hasil), planning intervention (perencanaan intervensi), implementation (implementasi) dan evaluation (evaluasi). Pada prakteknya kegiatan proses keperawatan di atas tidaklah selalu berurutan tetapi bisa dikerjakan pada waktu bersamaan/tumpang tindih (overlapping). Salah satu kegiatan yang penting dalam proses keperawatan adalah pengkajian keperawatan.

dokumentasi rencana tindakan keperawatan adalah menetapkan tujuan, menentukan kriteria hasil, dan menentukan rencana tindakan keperawatan. Kurang lengkapnya pencatatan pada format intervensi keperawatan berhubungan dengan kurang lengkapnya penulisan diagnosis keperawatan. Ketidak lengkapan penulisan intervensi keperawatan akan berdampak pada penetapan implementasi keperawatan. Tim peneliti berpendapat bahwa sebaiknya perawat patuh dalam menulis intervensi keperawatan sesuai rumusan yang telah ditetapkan.

Perawat dalam meningkatkan mutu dokumentasi perlu dukungan melalui pendidikan untuk mengetahui langkah-langkah dalam menghubungkan diagnosis dengan intervensi, khusus untuk etiologi dan untuk mengidentifikasi hasil asuhan 
keperawatan. Peningkatan mutu dokumentasi membuktikan bahwa penerapan $Q$ DIO berguna sebagai instrumen audit untuk dokumentasi keperawatan dan harus dikembangkan sebagai fitur yang terintegrasi secara elektronik. dokumentasi implementasi keperawatan merupakan catatan tentang tindakan yang diberikan kepada klien. Salah satu petunjuk yang perlu diperhatikan dalam mendokumentasikan implementasi keperawatan adalah beri tanda tangan dan nama jelas dari perawat yang melakukan tindakan.

TerdapatTerdapat 3 komponen diagnosa keperawatan yaitu problem, etiologic dan symptom. Problem merupakan alasan dari pemberian asuhan keperawatan, dimana keadaan yang menyimpang dari keadaan normal yang seharusnya tidak terjadi. Etiologic factor penyebab terjadinya penyimpangan status normal menjadi suatu masalah yang harus diatasi dan symptom yang merupakan kumpulan komponen data subyektif dan obyektif hasil dari pengkajian keperawatan.

\section{Pembahasan}

Keperawatan merupakan suatu bentuk pelayanan profesional bersifat humanistik, menggunakan pendekatan holistik, dilakukan berdasarkan ilmu dan kiat keperawatan, berorientasi kepada kebutuhan objektif klien. Praktek keperawatan mengacu pada standar professional keperawatan dan menggunakan etika keperawatan sebagai tuntutan utama.Proses keperawatan terdiri dari lima tahap, yaitu pengkajian, diagnosa, perencanaan, implementasi, dan evaluasi. Proses keperawatan dilakukan untuk membantu perawat menentukan intervensi keperawatan yang tepat. Menulis dokumentasi keperawatan yang tidak lengkap dan tidak akurat dapat mengurangi mutu layanan keperawatan. Menulis dokumentasi keperawatan yang tidak sesuai dengan standar akan menyebabkan kesalahan diagnosis dan pelaksanaan tindakan yang tidak tepat Ketidak lengkapan dokumen dan ketidakpatuhan dengan standar yang ditentukan akan membuat sulit untuk membuktikan bahwa tindakan keperawatan telah dilakukan dengan benar.

Diagnosa merupakan salah satu tahap dalam proses keperawatan, yang dilakukan setelah pengkajian. Diagnosa keperawatan adalah proses menganalisis data yang didapatkan melalui proses pengkajian untuk menegakkan diagnosa. Sebelum merumuskan diagnosa, perawa memiliki tanggung jawab untuk mengenal 
atau mengidentifikasi masalah kesehatan klien. Untuk mengidentifikasi kebutuhan klien, perawat harus lebih dulu menentukan apakah masalah kesehatan pasien tersebut aktual atau potensial. Masalah kesehatan aktual adalah masalah ynag dialami atau dirasakan pasien, seperti gangguan pola tidur yang berhubungan dengan lingkungan yang bising. Sedangkan masalah kesehatan potensial atau beresiko mewaspadakan perawat pada pentingnya intervensi pencegahan.

Diagnosa keperawatan sejahtera telah didefinisikan dalam berbagai pustaka. mendefinisikan diagnosa keperawatan sejahtera sebagai suatu diagnosa yang menjelaskan respons manusia terhadap tingkat kesejahteraan individu, keluarga, atau komunitas yang memiliki potensi untuk meningkat pada kondisi yang lebih tinggi. Sedangkan Carpenito (1995) menyatakan bahwa diagnosa kesejahteraan adalah satu bagian pernyataan yang hanya meliputi satu label di mana klien menginginkan tingkat fungsi yang lebih tinggi. Pada dasarnya menurut Stolte, Carpenito mengusulkan bahwa diagnosa kesejahteraan hanya digunakan pada kasus yang berfokus pada perbaikan fungsi dan tujuannya adalah kemajuan dari satu tingkat kesejahteraan ke tingkat kesejahteraan yang lebih tinggi dilakukan berdasarkan ilmu dan kiat keperawatan, berorientasi kepada asuhan keperawatan yang benar atau rasional.

Pengalaman menunjukkan bahwa sering sekali perawat kesulitan dalam menentukan diagnosis keperawatan spesifik yang dialami oleh pasien.Hal ini mungkin karena pengkajian keperawatan yang tidak terstruktur dengan baik.Pengalaman menunjukkan bahwa pengkajian yang dilakukan oleh perawat tidak mempunyai urutan yang runut dan terkait dengan diagnosis keperawatan.Sering terjadi perawat mempunyai data tertentu tetapi kebingungan untuk menentukan data tersebut mendukung diagnosis keperawatan yang mana. Atau sebaliknya perawat mempunyai prediksi pasien mempunyai diagnosis tertentu tetapi tidak tahu data apa yang perlu dikaji untuk mendukung diagnosis tersebut muncul. Pelayanan keperawatan yang diterima oleh pasien ternyata lebih buruk dari harapan pasien, maka pasien tersebut merasa tidak puas karena merasa kecewa. Apabila pelayanan keperawatan yang diterima oleh pasien ternyata sebanding dengan harapan pasien maka pasien merasa puas (senang). Kepuasan pasien adalah suatu prioritas yang akan membantu perawat dalam memberikan pelayanan keperawatan agar pasien mau berparisipasi selama perawatan. 
Asuhan keperawatan adalah faktor penting dalam kelangsungan hidup pasien dan aspek-aspek pemeliharaan, rehabilitatif dan prefentif perawatan kesehatannya. Menurut Shore, untuk sampai pada hal ini, profesi keperawatan telah mengidentifkasi proses pemecahan masalah yang "menggabungkan elemen yang paling diinginkan dari seni keperawatan dengan elemen yang paling relevan dari sistem teori, dengan menggunakan metode ilmiah". Proses keperawatan ini diperkenalkan pada tahun 1950-an sebagai proses yang terdiri atas tiga tahap : Pengkajian, perencanaan dan evaluasi yang didasarkan pada metode ilmiah pengamatan, pengukuran, pengumpulan data dan penganalisaan temuan. Kajian selama bertahun-tahun, penggunaan dan perbaikan telah mengarahkan perawat pada pengembangan proses keperawatan menjadi lima langkah yang konkret (pengkajian, identifikasi masalah, perencanaan, implementasi dan evaluasi) yang memberikan metode efisien tentang pengorganisasian proses berfikir untuk pembuatan keputusan klinis.

Proses keperawatan adalah kerangka kerja untuk memberikan pelayanan keperawatan yang profesional dan berkualitas. Proses keperawatan adalah metode pengorganisasian yang sistematis dalam melakukan asuhan keperawatan pada individu, kelompok, dan masyarakat yang berfokus pada identifikasi dan pemecahan masalah dari respons pasien terhadap penyakitnya. Tahap-tahap dalam proses keperawatan adalah pengkajian, diagnosis keperawatan, perencanaan, pelaksanaan, dan evaluasi. Diagnosis keperawatan adalah suatu bagian integral dari proses keperawatan. Diagnosis keperawatan ditetapkan berdasarkan analisis dan interprestasi data yang diperoleh dari pengkajian keperawatan klien. Diagnosis keperawatan memberikan gambaran tentang masalah atau status kesehatan klien yang nyata (aktual) dan kemungkinan akan terjadi, dimana pemecahnya dapat dilakukan dalam batas wewenang perawat.

Hasil observasi di rumah sakit bahwa untuk jumlah diagnosa keperawatan yang muncul pada satu orang pasien rata-rata satu jenis diagnosa keperawatan saja, padahal diagnosa keperawatan bisa ditegakkan berdasarkan respon pasien. Diagnosa keperawatan tunggal tersebut, bisa jadi dikarenakan pengkajian yang kurang lengkap, atau bisa dikarenakan ketidaktahuan perawat dalam menentukan diagnosa lain yang sesuai. Pada sisi lain pada diagnosa keperawatan, ditemukan adanya pernyataan nama diagnosa yang berbeda, meskipun respon masalah pasien sebenarnya sama. Jadi disini 
tidak ada keseragaman bahasa dalam nama diagnosa keperawatan. Sehingga seringnya diagnosa itu ditemukan menjadi hal yang terpenting dalam keperawatan. Perawat dapat mempersiapkan sumber daya untuk mengatasi diagnosa keperawatan tersebut. Rumah sakit juga akan menyiapkan kebutuhan sumber daya yang diperlukan untuk kepentingan diagnosa tersebut.

dokumentasi evaluasi keperawatan merupakan catatan tentang indikasi kemajuan pasien terhadap tujuan yang akan dicapai. Evaluasi keperawatan menilai keefektifan perawatan dan mengkomunikasikan status kesehatan klien setelah diberikan tindakan keperawatan serta memberikan informasi yang memungkinkan adanya revisi perawatan sesuai keadaan pasien setelah dievaluasi Beban kerja mempengaruhi mutu perawat dalam mendokumentasikan asuhan keperawatan. Hal ini dikaitkan dengan motivasi kerja, bahwa terdapat hubungan yang signifikan antara motivasi responden terhadap pendokumentasian asuhan keperawatan Beban kerja mempengaruhi mutu perawat dalam mendokumentasikan asuhan keperawatan. Hal ini dikaitkan dengan motivasi kerja, bahwa terdapat hubungan yang signifikan antara motivasi responden terhadap pendokumentasian asuhan keperawatan Dokumentasi asuhan keperawatan menggunakan pendekatan proses keperawatan yang terdiri dari pengkajian, perumusan diagnosa, perencanaan, pelaksanaan, dan evaluasi sebagai metode ilmiah penyelesaian masalah keperawatan pada pasien untuk meningkatkan outcome pasien Perawat dituntut untuk selalu melaksanakan ketepatan diagnosa keperawatan dala asuhan keperawatan terhadap pasien.

Hasil observasi di rumah sakit bahwa untuk jumlah diagnosa keperawatan yang muncul pada satu orang pasien rata-rata satu jenis diagnosa keperawatan saja, padahal diagnosa keperawatan bisa ditegakkan berdasarkan respon pasien. Diagnosa keperawatan tunggal tersebut, bisa jadi dikarenakan pengkajian yang kurang lengkap, atau bisa dikarenakan ketidaktahuan perawat dalam menentukan diagnosa lain yang sesuai. Pada sisi lain pada diagnosa keperawatan, ditemukan adanya pernyataan nama diagnosa yang berbeda, meskipun respon masalah pasien sebenarnya sama. Jadi disini tidak ada keseragaman bahasa dalam nama diagnosa keperawatan. Sehingga seringnya diagnosa itu ditemukan menjadi hal yang terpenting dalam keperawatan. Perawat dapat mempersiapkan sumber daya untuk mengatasi diagnosa keperawatan tersebut. Rumah sakit juga akan menyiapkan kebutuhan sumber daya yang diperlukan untuk kepentingan diagnosa tersebut. 


\section{Penutup}

Dalam tahap diagnosa, perawat berperan secara independen, artinya perawat dapat merumuskan sendiri diagnosanya, bertanggung jawab terhadap diagnosa yang dirumuskan, membedakan peran perawat dengan peran dokter, serta menunjukkan bahwa asuhan keperawatan tersebut bermutu, mempunyai kualitas, dan atas dasar pendidikan perawat. Diagnosa keperawatan adalah proses menganalisis data yang didapatkan melalui proses pengkajian untuk menegakkan diagnosa. Dalam merumuskan atau menegakkan diagnosa, perawat harus dapat melakukannya dengan tepat. Diagnosa yang tepat akan menjadi dasar dalam menentukan intervensi yang bermutu dan berkualitas Diagnosis keperawatan juga harus ditingkatkan lagi didalam pelayanan rumah sakit dan fasilitas kesehatan lainnya agar seragam, akurat, dan tidak ambigu. Penegakan diagnosis keperawatan sebagai salah satu komponen standar asuhan keperawatan perlu dilaksanakan dengan baik sebagaimana yang diamanahkan dalam undang-undang No.38 tahun 2014 tantang keperawatan pada pasal 30 bahwa dalam menjalankan tugas sebagai pemberi asuhan keperawatan, perawat berwenang menetapkan diagnosis keperawatan.

Diagnosa keperawatan sejahtera telah didefinisikan dalam berbagai pustaka. mendefinisikan diagnosa keperawatan sejahtera sebagai suatu diagnosa yang menjelaskan respons manusia terhadap tingkat kesejahteraan individu, keluarga, atau komunitas yang memiliki potensi untuk meningkat pada kondisi yang lebih tinggi. Sedangkan Carpenito (1995) menyatakan bahwa diagnosa kesejahteraan adalah satu bagian pernyataan yang hanya meliputi satu label di mana klien menginginkan tingkat fungsi yang lebih tinggi. Pada dasarnya menurut Stolte, Carpenito mengusulkan bahwa diagnosa kesejahteraan hanya digunakan pada kasus yang berfokus pada perbaikan fungsi dan tujuannya adalah kemajuan dari satu tingkat kesejahteraan ke tingkat kesejahteraan yang lebih tinggi dilakukan berdasarkan ilmu dan kiat keperawatan, berorientasi kepada asuhan keperawatan yang benar atau rasional.

\section{Daftar pustaka}

1. Apriyani, H. (2015). Identifikasi Diagnosis Keperawatan Pada Pasien di Ruang Paru Sebuah Rumah Sakit. Jurnal Keperawatan. 11(1): 107-111. 
2. Atmanto, arif puji,dkk ( 2020 ) Efektifitas pedoman pendokumentasian diagnosa dan intervensi keperawatan berbasis android terhadap peningkatan mutu dokumentasi keperawatan di ruang rawat inap. Jurnal Keperawatan dan Kesehatan Masyarakat STIKES Cendekia Utama Kudus 9(1) 2252-8865

3. Astar, F. dkk. (2018). Pengaruh Pelayanan Asuhan Keperawatan Terhadap Kepuasan Pasien di Puskesmas Takalala Kabupaten Soppeng. Journal of Management. 1(2): 33-57.

4. Candra Saputra, Yulastri Arif, Fitra Yeni.2019. FAKTOR YANG BERHUBUNGAN DENGAN KUALITAS DAN KELENGKAPAN DOKUMENTASI KEPERAWATAN. Jurnal IImiah STIKES Kendal. 9 (3)

5. Iyer, P.W.; Camp, N.H. (2004). Dokumentasi keperawatan suatu pendekatan proses keperawatan. Edisi 3. Jakarta: EGC

6. Muryani, Endang Pertiwiwati, Herry Setiawan.2019. kualitas pendokumentasian asuhan keperawatan diruang (Studi di RSUD Kalimantan Tengah).jurnal Nerspedia, 2 ( 1 )

7. Novieastari, E. (2013). Diagnosis Keperawatan Sejahtera. Jurnal Keperawatan Indonesia, 7(2), 77-88.

8. Rofi'i, M., Warsito, B. E., Santoso, A. \& Ulliya, S. (2018). Diagnosa Keperawatan Yang Sering Ditegakkan Perawat Pada Pasien Tuberkulosis Paru Di Rumah Sakit. Jurnal Kepemimpinan dan Manajemen Keperawatan, 1(2), 1-8.

9. Simamora, R. H., Bukit, E., Purba, J. M., \& Siahaan, J. (2017). Penguatan 
kinerja perawat dalam pemberian asuhan keperawatan melalui pelatihan ronde keperawatan di rumah sakit royal prima medan. Jurnal pengabdian kepada masyarakat, 23(2), 300-304.

10. Simamora, R. H. (2019). Socialization of Information Technology Utilization and Knowledge of Information System Effectiveness at Hospital Nurses in Medan, North Sumatra. Editorial Preface From the Desk of Managing Editor..., 10(9).

11. Tokan , kopan pius, dkk (2020) Penerapan format baru pendokumentasian keperawatan di poli rawat jalan puskesmas.jurnal kesehatan primer 5 (1) 2549-4880

12. Wulandini, P., Krianto, T. \& Priwahyuni, Y. (2016). Faktor-Faktor Yang Berhubungan Dengan Pendokumentasian Asuhan Keperawatan Di Rumah Sakit Jiwa. Jurnal Keperawatan, 12(2), 131-142. 